\title{
Identity in Teaching a Second Language: The Narrative Journey of a Saudi Female
}

\author{
Nehad Adel Alnahhas ${ }^{1, *}$ \\ ${ }^{1}$ Department of Language and Literacy Education, The University of British Columbia, Vancouver, Canada \\ *Correspondence: Department of Language and Literacy Education, The University of British Columbia, Vancouver, \\ Canada. E-mail: nehad.alnahhas@gmail.com/King Abdul Aziz University (English Language Institute), Jeddah, \\ Saudi Arabia. E-mail: nalnahhas@kau.edu.sa
}

$\begin{array}{ll}\text { Received: January 16, } 2016 & \text { Accepted: February 25, } 2016 \quad \text { Online Published: March 24, } 2016 \\ \text { doi:10.5430/ijelt.v3n2p1 } & \text { URL: http://dx.doi.org/10.5430/ijelt.v3n2p1 }\end{array}$

\begin{abstract}
The purpose of this paper is to introduce the narrative journey of myself as an English language teacher and learner who came from Saudi Arabia to Canada to do my master's degree in the Teaching English as a Second Language (TESL) program. Having three years of experience in teaching, I found that to be a good opportunity to improve myself through expanding my knowledge, skills, and qualifications through doing that program which introduces me to a number of resources. I came to Canada with the aim of gaining knowledge and experience from a different culture. Therefore, I have felt a shift and a movement in my identity, which provides me with a sense of direction in my future goals. Hence, the paper discusses this movement by incorporating identity theory and several other theories connected to it, in order to envision the journey of my career as a teacher. It is in reality a narrative identity changing across time and space.
\end{abstract}

Keywords: teacher identity; investment; community of practice; imagined community; teachers and teaching; English education in Saudi Arabia; novice teachers; motivation

\section{Geographical and Cultural Context of Saudi Arabia}

The Kingdom of Saudi Arabia is located in the Arabian Peninsula with a population of approximately 29 million (2012 est.). Arabic is the official language and Islam is the official religion. The real beginning of education started in 1925 and since that time, education has undergone several developments. According to a recent estimation in 2012 , Saudi Arabia has achieved a high rate in literacy which is about 96\%, "The Kingdom brought down the level of illiteracy in the country from 60 percent in 1972 to 4 percent in 2012," said a statement issued by the Ministry of Education on the occasion of the World Day of Illiteracy Eradication Friday. ("Saudi Arabia achieves, 2012").

Saudi women's education started in 1960s and since that time, the government has been supporting women's education, which is demonstrated in the hundred schools and campuses at almost all universities. "Women's status in education in Saudi Arabia has been changing, and the Ministry of Higher Education has considered sending talented women abroad to finish their studies in high-demand subjects" (Hamdan, 2005, p. 59). The last part of my paper will explore learning English, education, and Islam in more detail to show the fact that education is highly promoted in Islam.

\section{Teachers and Teaching}

\subsection{Who are Teachers? What is Teaching?}

In Saudi Arabia, teachers are moral agents who are responsible for transforming and delivering knowledge to learners for the purpose of empowering them and giving them access to the educational world. They practice different kinds of interactions between themselves and their learners for the purpose of learning and gaining knowledge. Claiming the identity of a teacher means the transformation and adaption of such an identity that is full of commitment and responsibilities of leading a new generation.

Teaching is seen as a process of carrying valuable knowledge and making it accessible and learnable to others. It is also viewed as "A much more complex cognitively-driven process affected by the classroom context, the teachers 
general and specific instructional goals, the learner's motivation and reactions to the lesson, the teacher's management of critical moments during a lesson" (Richards, 2008, p. 167).

\section{Imagined Communities (Anderson 1991)}

"Imagined communities refer to groups of people, not immediately tangible and accessible, with whom we connect through the power of the imagination" (Kanno \& Norton, 2003, p. 241).

\subsection{How Does That Connect to Teaching?}

Going back many years ago, when I took the decision to be an English language teacher, I did not know that I would advance to my master's degree. When I was in school, I was highly influenced by one of my teachers who motivated me and made me invest in learning English language. Thus I could say that the first step in learning English started by building the community of teachers in my future identity. The construction and the formation of the identity started quite early as I used my imagination to reach that community. Having a certain goal or a certain community to reach in my vivid imagination motivated me to focus on one salient ambition and face all the difficulties and challenges in order to ease those obstacles. In imagined community (Anderson, 1991), we feel a sense of belonging to that community even if we are not yet met, but hope to meet one day. Consequently, we start to feel familiarity and belonging to that community until we become part of it officially.

Choosing a certain identity for my future was shaped by several factors in my educational journey. For example, feeling belonging to the community of teachers paved the way to gain the power of envisioning myself as a real teacher and gave me an important sense of direction and place. Kanno and Norton (2003) state that, "...such communities include future relationships that exist only in the learner's imagination as well as affiliation such as nationhood or even transnational communities that extend beyond local sets of relationships" (p. 242). Thus, I built my imagined community in my mind and at the same time, I started to climb the stairs step by step to reach it in order to be a part of it. That is clearly seen also in my students who were imagining themselves in their future communities. Thus, they started to shape their educational path and to invest in their learning in order to reach their future goals. Once the learner starts to imagine the future, he or she would also imagine the way to the future as coming to reality one day.

Imagined identity not only affected me in school but also during my undergraduate and graduate studies. Even though I became an English language teacher, I still have a certain identity in my mind for my future community after graduating from my master's degree program. My identity changed across time and space as I moved to a new society and culture where I have experienced new challenges and where I was introduced to extensive data resources at the University of British Columbia (UBC).

After moving to a new stage, which is doing my master's degree, my identity changed to a learner again in order to get access to the new step. Since language is the main source of self in this situation, my social identity or subjectivity (Weedon, 1987) was constructed in relation to others, especially the social world. In that sense, social identity is subject to change (Norton Peirce, 1995) and that change took place in the new shift from a teacher to a learner again where I met new people from different parts of the world, and where I learned more skills and practices. The investment in this stage is for a greater purpose, which is also related to my future identity.

Imagination also plays a role in my master's studies since I am expecting myself to reach a goal at the end of this program. Imagining myself in my future career helps me to break the barriers that I am facing. In addition to that, my future identity encourages me to invest my time and resources in learning and to access the symbolic and material knowledge of this experience of learning.

\section{Investment and Motivation}

\subsection{A Broker and Investor}

Investment reflects "The complex relationship of language learners to the target language and their sometimes ambivalent desire to speak it" (Norton Peirce, 1995, p. 9).

Several factors led me to invest in learning English. Pittaway (2004) described this relationship as a broker and investor, in which we invest and then there is a return on that the investment, particularly in terms of self-image. Hence, "An investment in the target language is also an investment in a learner's own identity, an identity which is constantly changing across time and space" (Norton, 2000, P. 11). 
Motivation empowers learners to acquire better language skills in the target language. In my case, many influential factors affected and motivated me. One of them is the teacher who was my future inspiration. In addition to that, my long term goal to come to Canada served actually as a motivator in terms of writing the goals in my diary to use them later as a witness for my accomplishments. The goal or the aim that one imagines at the end of the journey keeps pushing us through motivation to turn it to reality. Moreover, the decision that I took in the second year at the university after most of my friends withdrew from the English department because of its difficulty, generated my motivation and self-confidence to continue studying English, which was reflected positively on myself. As Norton Peirce (1995) suggested "An investment in the target language is also an investment in a learner's own identity, an identity that is constantly changing across time and space" (p. 18).

Gardner (1985:54) suggested that "Self-confidence... develops as a result of positive experiences in the context of the second language and serves to motivate individuals to learn the second language" (as cited in Norton Peirce, 1995, p. 11). Every successful step that we build is actually adding to our motivation to continue to work hard. Being able to succeed in learning English, to be an English language teacher, to get a scholarship, and to be accepted at UBC, are all successful stages in my life which are reflected positively on myself and motivated me towards moving up and continuing my journey of learning. The more successful steps we make, the more motivated we are. Failure does not mean that we are not able to reach goals but in fact it means pushing us towards a new way with a richer experience. Graduating from my master's degree, going back to Saudi Arabia, and reaching the future community where I want to work, are all considered to be positive future steps that will generate my motivation and investment to apply what I have learned in the real world.

Teachers can also invest in their learners by distinguishing them in accordance to their levels and abilities in order to find the effective ways of teaching them in line with their various needs and backgrounds. In the meantime, they are investing in themselves as a means to advance their own learning. The more they succeed in making the content learnable, the more effective they feel as teachers.

\section{Negotiation of Identities}

Identity is defined as "How individuals see themselves and how they enact their roles within different settings" (Burns \& Richards, 2009, p. 16).

\subsection{Multiple Identities?}

After graduating from my bachelor program at the university in Saudi Arabia, I became officially an English teacher. The dream came true and it was time to gain experience and to become a part of the school's community. Here my identity shifted from a learner to a teacher with a more powerful identity. I knew that being a teacher would give me the power to apply the knowledge and skills that I had already learned and developed.

Miller pointed out that "identity is viewed as rational, negotiated, constructed, enacted, transforming, and transitional" (as cited in Burns \& Richards, 2009, P. 220). For teachers it is about constructing and developing their identity within the social context. Norton Peirce (1995), indicated that identity is multiple and a site of a struggle, as well as continuously changing over time. Varghese (2006) defined teacher professional identities in terms of the influences on teachers, how individuals see themselves, and how they enact their profession in their settings.

The identity that one claims is actually affected by several aspects. Every person is exposed to different identities to navigate that determine the future community for him or her. In the end, the identity that we choose is based on human agency. Mathew's (2000) Cultural Supermarket shows that we are can choose from many identities but our choice is affected by other factors. As he said "...there are social structures within which individuals exist which constrain the amount and scope of choice available to individuals" (as cited in Block, 2006/2010, p. 250). The claim of my teacher identity could be different if I were affected by my uncle's views, which suggest that it is better to be a doctor rather than an English language teacher. It caused conflicts since I knew that it was going to be my choice and I had to be careful about that. Therefore, after I made the decision to learn English and to be a teacher, subjectivity took place, which indicates the new sense about myself. As Weedon (1997) argued that "...language not only defines institutional practices, but serves to construct our sense of ourselves - our subjectivity" (as cited in Norton and McKinney, 2011, p. 78).

The shift in one's identity could happen due to the cultural, economic and social changes. Shifting from a learner to a teacher meant to me more responsibilities. It also meant more accessibility to new resources in order to be qualified and experienced. To me, learning a second language means constructing a new identity in a Saudi society, which believes in traditional values and that Medical Sciences are the optimal studies. 
Being able to speak a second language strengthens one's identity especially the social one. West (1992) suggested that "Identity related to desire - the desire for recognition, the desire for affiliation, and the desire for security and safety" (as cited in Norton, 1997, p. 410). My social identity changed in two different situations: the first situation was when I became an official teacher, and the second situation was when I came to Canada. Meeting other people from other cultures expanded my knowledge and because I have to speak the second language, I realized the importance of enacting my own identity, especially if the other interlocutors are from different cultures. Weedon (1997) argued that it is in language that the individual constructs her subjectivity, which she saw as "the conscious and unconscious thoughts and emotions of the individual, her sense of herself, and her ways of understanding her relation to the world" (as cited in Norton \& Toohey, 2011, p. 417). So when social identity is constructed, the learner becomes active, and social interactions begin to take place. Accordingly, I am expecting myself to change again once I join a new future community, as numerous interactions would take place.

Teacher identity includes language teacher identity, which means that two main responsibilities are integrated and intertwined. The first responsibility is to become a teacher. This responsibility is shared with others no matter what subject they are teaching. This process involves the common characteristics for all teachers. They share the same values and the same qualities. The second responsibility is to be a language teacher, which requires more qualifications and qualities, especially if the language is a second one in that community. According to Reeves (2009) "As teachers repositioned themselves, they also changed their pedagogical approaches to correspond to the new identity position" (p. 35). Thus, when teachers become officially teachers, they start to focus on their new identity to reform it and shape it according to the circumstances of the new environment.

\section{Knowledge and Principles}

\subsection{How Those Are Acquired?}

Becoming an English language teacher means, “... becoming part of a worldwide community of professionals with shared goals, values, discourse, and practices but one with a self-critical view of its own practices and a commitment to a transformative approach to its own role" (Richards, 2008, p. 161).

One essential component of teacher identity is both the content and the values that teachers bring to the class. During teaching, I had to include and search for current topics and issues and discuss them with my students. We made a bulletin board for weekly topics such as the environment week, traffic week, and many others. My students posted short articles, proverbs, and suggestions on this board. At the same time, we discussed those topics in my extra classes in order to strengthen the students' verbal skills.

Being professional means consonantly acquiring different kinds of knowledge, whether local or international knowledge, since the acquisition of such knowledge is part of one's changing identity. This knowledge might be implicit, such as beliefs and theories in a teacher's practical actions. It might also be explicit knowledge or practical knowledge that teachers use in facilitating their classroom to transform the content into learnable and accessible forms (Richards, 2008). Another kind is the independent professionalism, "Which refers to teachers' own views of teaching and the processes by which teachers engage in reflection on their own values, beliefs, and practices" (Richards, 2008, p. 161). In general, there are two main kinds of knowledge that affect teaching: one relates to the method and techniques of teaching, the curricular goals and objectives, and the instructional activities and tasks; the other kind of knowledge is about teachers' beliefs and views of good teaching, and their personal, and subjective philosophy of teaching. (Richards, 1996, p. 284).

When teachers convey knowledge to the students, they usually employ different conceptual units, as Woods (in press) distinguished them into categories such as: overall, global, intermediate, and local conceptual units (Richards, 1996). They all work together to serve various purposes that teachers tend to use in their classrooms, including teaching the subject matter and transforming content into learning. Furthermore, they employ different principles or maxims (Richards, 1996) in order to achieve the objectives of the lessons and fulfill students' needs. One of these principles is the progressive one, which involves checking the development of the students' abilities and needs, especially students with additional learning needs. For example, I had to keep an evaluation sheet for each student that included their academic performance and progress during the year.

Another maxim is the authenticity principle, which involves a good social relationship between the teacher and the students. Other principles are related to classroom management, using an effective lesson plan, and seeking many ways to encourage students' learning. For instance, one of the strategies that was effective in my class was the use of PowerPoint presentation and projectors to incorporate Big Fish Games in teaching certain vocabulary. As teachers 
become aware of all those principles, they employ different activities and tasks, such as group discussions to create a social atmosphere for their students. Therefore, teachers adapt the classroom practices and lesson plans according to their students' levels to improve learning.

\section{Development of Career Identity}

\subsection{How Do They Progress?}

When I was teaching, I kept a file for each class that included the activities, quizzes, games, lesson plans, and all my strategies at that time. Regularly, I tried to modify my methods of teaching to accommodate my students' abilities and include their personal needs. As teachers develop their methods and techniques of teaching, they pay attention to their instructional skills (Shulman, 1987) "Which refers to strategies for organizing and presenting content and for the effective management of teaching and learning in the classroom" (Richards, 1996, p. 293). It includes their mastery of their procedures and techniques, and developing them to advance successfully in their teaching.

Their image about themselves is also related to teacher identity and it is of vital importance to their performance in the classroom because the more positive their image, the more engagement in teaching will happen. Moreover, it is crucial in particular, as Nias (1989:155) maintained "...to the way in which they construe the nature of their job" (as cited in Bullough Jr., 1993, p. 91).

Teacher development is also socially constructed as there are many other factors that impact the teacher. The school community itself is a social community where various identities are constructed and reformed. Varghese et al., (2005) stated that "It is a social matter because the formation, negotiation, and growth of teacher identity is a fundamentally social process taking place in institutional settings such as teacher education programs and schools" (p. 39) . The practicum training that I took when I was in the university included three different interlocutors: the school, the sponsor teacher, and my supervisor who was responsible for evaluating me. In addition to myself image, the other three interlocutors had to provide me with evaluation about my teaching. The three different evaluations supplied and added to my own experience and helped me later in building my identity as a teacher. Thus, my identity changed according to the other staff members in the school. Even after becoming a certified teacher, I was looking for feedback, comments, instructions, and emotional support from other teachers and my supervisors in order to improve my teaching skills. As Fuller and Brown (1975) suggest “...when novice teachers begin their first year of teaching, they require assistance and support as they attempt to navigate through their experiences" (as cited in Farrell, 2009, p. 264).

A crucial component of teacher development is the collaborative experience within and beyond the classroom (Johnston, 2009). It is defined as, "Any sustained and systematic investigation into teaching and learning in which a teacher voluntarily collaborates with others involved in the teaching process, and in which professional development is a prime purpose" (Johnston, 2009, p. 342). As a teacher, I always aimed at developing my skills and to be more professional in my career and that is by collaborating with different interlocutors in the school such as teachers and administrators. Johnston (2009) suggested four major possibilities: First, teachers can collaborate with other language teachers as they share the same qualifications, experience, and objectives. When I was teaching, I always visited other language teachers' classrooms and learned from their instructional strategies. Second, the collaboration can also be between teachers and university-based researchers aiming at dealing with the various kinds of issues that face educators, since researchers have access to greater resources and materials. Third, teachers can collaborate with their students for many educational purposes to improve their skills. Since teachers have the power, they tend to use it to reach certain pedagogical goals. Sometimes, the collaboration can take place beyond the classroom to involve parents and guardians. For example, parents' meetings were conducted twice a year to discuss their children's performance and progress. However, sometimes, private meetings were needed when one of the students was facing issues that were beyond a teacher's abilities to solve. In this case, parents would be able to figure it out by themselves and try to solve it at home. Finally, teachers can collaborate with other members in the school such as the administrators, supervisors, and others.

\section{Practicum Training}

\subsection{On the Way to be a Certified Teacher}

Several terms are used to describe the practicum training, defined by Gebhard (2009) as "Practice teaching, field experience, apprenticeship, practical experience, and internship"(p. 354). It usually provides various opportunities for student-teachers, as Richards and Crookes (1988) (as cited in Gebhard, 2009 ) indicated these opportunities as: 
gaining practical classroom teaching experience, applying theory and teaching ideas from previous course work, discovering from observing experienced teachers, enhancing lesson-planning skills, gaining skills in selecting, adapting, and developing original course materials, expanding awareness of how to set their own goals related to improving their teaching (Crookes 2003). Also important is the ability to question, articulate, and reflect on their own teaching and learning philosophies, seeing their own teaching differently by learning how to make their own informed teaching decisions through systematic observation, and exploring their own and others' teaching. (Fanselow 1988; Gebhard and Oprandy 1999).

While doing my practicum training in one of the public schools in Saudi Arabia, we were asked to attend other teachers' classes to observe the strategies they use. Thus, I attended many classes for other trainers who were also doing their practicum. Some of them were teaching other subjects like History or Geography and we were asked to observe how they manage the class. Bailey et al., (2001) and Fanselow (1988, p. 115) indicated that "Observing teachers need not exclude other teacher-learners. Whether the observed teacher is experienced or not, the goal is the same - to see one's own teaching differently" (Gebhard, 2009, p. 357).

\section{Mentors or Supervisors}

Malderez (2009) defined mentoring, "The process of one-to one, workplace-based, contingent and personally appropriate support for the person during their professional acclimatization or integration, learning, growth, and development" (p.367).

When I was doing my practicum, my supervisors conducted daily meetings with us as a group of student-teachers. The meetings included discussions and suggestions for each class that we had. The supervisors also served as experienced mentors so that we could learn from their assessments. Therefore, it was effective, supportive, and valuable in terms of teaching progress. During the practicum training, student-teachers are mentored or supervised by an expert teacher working at the same school or coming from the university to evaluate them. They tend to assist trainees and evaluate their teaching skills by offering suggestions for improvement. Once trainees recognize the effectiveness of mentoring, it will reflect positively on their teaching experience.

According to Malderez (2009) mentors have actually two main jobs: first, their help in an ordinary sense, which means providing the materials for the trainees. In my practicum, the school's English teacher gave me some of her activities and other materials to learn from. Second is the scaffolding of the learning of the skills that the trainees learn from their experience. Thus, according to Yost et al., (2000) their further aims are to "Assist the mentee in linking and seeing the relevance of various kinds of knowledge derived from various sources (e.g., codified knowledge from books or studies, intuitive and often wordless knowledge derived from experience, skilled knowledge, which may or may not be consciously held), during the process of supporting the development of noticing, and professional learning, thinking and planning skills" (Malderez , 2009, p. 374).

\section{Novice Teachers}

Farrell (2009) defined them as "The ones who have completed their teacher education program including the practicum and have just commenced teaching in an educational institution" (P. 261).

\subsection{Swimming or Sinking?}

Although the practicum was beneficial in terms of practicing all the skills that I learned during my education, I considered myself a novice teacher during my first three years of teaching. I faced many challenges as I realized that it is a different experience. Novice teacher identity is always subject to change over time as teachers gain more experience. For them, becoming a teacher means significant changes through learning as they engage in teaching and strive to become more skilled in this area. During my initial years of teaching, I was eager to develop an area of expertise and become increasingly comfortable and flexible with my new identity. Therefore, as novice teachers learn and evolve, their practices change accordingly.

Ryan et al., (1980) indicated many challenges and difficulties for first year teachers. These are: "Personal life adjustment, teachers' expectations and perceptions of teaching, the strains of daily interactions, and the teaching assignment itself" (as cited in Parker et al., 1986, p. 30). From my own experience, dealing with a heavy teaching load and insufficient preparation time were my areas of difficulties during that period. I was asked to teach many classes, some of them were intermediate and others were elementary, so I had to spend my time preparing for different lesson plans and visual aids. Yet, I was able to balance and manage my time in order to avoid being 
overwhelmed. Bush (1983) argued that "New teachers develop a survival mentality and they have to learn to swim very quickly or sink" (as cited in Parker et al., 1986, p. 31).

There are two general stages of developmental challenges according to Fuller and Brown (1975): The first one is described as "survival and mastery... the second one is resistance to change or staying open to adaptation and change of practice..." (Farrell, 2009, p. 263). During my first year of teaching, my main concern was to establish myself in the school. Moreover, I needed to prove that I was qualified to teach there and to manage the classroom, especially when supervisors came to evaluate me and see my performance. Later on, I developed another kind of concern, which is assessing my students' learning and their abilities to understand the content. Another challenge was that most of my students learned English late in their lives. Some of them were doing well but others were struggling since they lacked the basics. For an intermediate level, students should be able to construct sentences and to write paragraphs, but unfortunately they could not do that. I could not just focus on teaching them the curriculum without correcting the other problems. I felt that it was my responsibility to help them to achieve a higher level of English language proficiency, otherwise my goals were not completely achieved. Here I faced conflicts between my desire to improve their language skills and the school's required curriculum. It took me so much time and effort as to try to balance between the two different goals. Furness (2008) indicated in his study a number of major themes regarding a teacher's challenges such as: frustration, exclusion, and nervousness; passivity and boredom; survival; interaction with students; interaction with colleagues; and gaining confidence and knowledge (as cited in Farrell, 2008, p. 152). As they move to a new stage in their lives, they suffer from these challenges due to the responsibilities that are increasing. The challenges also emerge as they try to survive in the community where they will teach. Gradually, the further they get into teaching, the more confident they become and the more experience they gain.

\section{Communities of Practice (Lave \& Wenger 1991)}

Teacher identity also develops in relation to communities of practice. Community of practice includes schools as educational institutions, and classrooms where teaching takes place. In classrooms, the interactions occur between the teacher and the students, and also among the students themselves. Students usually perform different tasks and activities in the classroom and learn from each other. It is where they practice their abilities and develop their language skills. They even develop their knowledge, negotiate it, and construct it.

Lave and Wenger (1991) drew attention to an important point regarding novice teachers, as they suggest, “... novices engage in learning not for its own sake, but they learn so that they can participate in the practices of the community to which they wish to belong" (as cited in Kanno \& Stuart, 2011, p. 239). Therefore, all novice teachers are considered to be newcomers to the language practice of the school. Danielewicz (2001, p.168) argued, "The course room should be a site where teacher-learners create and experience different representations of themselves" (as cited in Singh \& Richards, 2006, p. 167). Employing several strategies, such as changing students' sitting plan and assigning different roles to them, promote changing the environment in the classroom as it becomes more active and social. Through discussions, learners will reveal their main problems and show their teachers that they understand the content of the curricula.

\section{Learning to Teach}

All my previous experience in teaching gave me an opportunity to integrate my prior assumptions and beliefs about teaching, and the reality of teaching and implementing new strategies. Thus, after almost three years of teaching, I began to see my experience as a valuable one because it enhanced my identity. It is not only about teaching students but it is actually a long process of learning new skills subconsciously, and that is the accumulation of experiences. In the meantime, working at the same school for three years gradually enhanced the relationship with my students, and also with my co-workers, as a result of supportive and informative leadership, which strongly affected my attitude towards teaching. Britzman stated that "Learning to teach is always the process of becoming, a time of formation and transformation, of scrutiny into what one is doing and who one becomes" (as cited in Flores, 2001, p. 135). Novice teachers develop what is called the conception of self as teachers and formulate their identity (Flores, 2001). "Beginning teachers strongly believe that professional learning comes mostly from the experience" (Flores, 2001, p. 139). Progressively, teachers are influenced by three main types of experience: their previous experience, their education program, and their interactions with other teachers and co-workers in the same institution.

Teachers often learn how to respond to their students in a classroom and gain more experience as time passes. According to Johnson (1992) there are four main kinds of responses. The first one is called deficient response, which takes place when no response is made and the teacher seeks to explain and check the student's knowledge. This 
category of response aims to involve learners and elicit their reactions. Another response is the initiation, which involves a teacher's response to their students. Sometimes the teacher provides an explanation for other students in order to clarify the idea. At other times, the teacher may elicit other students' response for the purpose of providing more information. Another kind of response is the elicited response, which involves a teacher's feedback and paraphrasing of the student's answer to confirm whether it is correct or not.

Being a non-native speaker of English gave me a number of advantages when teaching my students. Since I experienced their situation and some of their challenges when I was learning English, I was able to ease the difficulties that they were facing, which empowered my identity as a teacher. As Llurda (2004)- paraphrasing Kramsch (1997)- mentioned in his article about the advantages of non-native speaker teachers, "Non-native speaker teachers are endowed with the privilege of bilingualism, as their experience of switching back and forth from their own language to the target one enhances their understanding of the demands of the learning situation" (p. 318). Therefore, the shift of my identity from a learner to a teacher gave me an opportunity to understand the requirements for learning and teaching the second language.

Identity as a social practice is constructed through several interactions. Teachers were once students and they develop their career identity in relation to many social interactions with other, including their students, other colleagues, the practicum, and their education. “ Teacher's knowledge and beliefs are constructed through and by the normative ways of thinking, talking, and acting that have been historically and culturally embedded in the communities of practice in which they participate as both learners and teachers" (Johnson, 2009, p. 17). They even develop their knowledge and cognitive skills through their interactions with the social and physical tools such as textbooks and knowledge transmission or teaching.

With all the previous factors, teaching has to be effective and it also has to fulfill the needs of the learners. Uddin \& Salam (2010) maintained that, "The main purpose of teaching is to stimulate, inspire, and motivate the students so that they appreciate the importance of the subject" (p. 32). It is a constant systematic approach that includes objectives, content, methods, media, and assessment (Uddin \& Salam, 2010). Above all, it should be planned accurately in order to achieve the expected changes in the students' learning.

\section{Reading Journals and Discussions in Seminars}

\subsection{My Experience at UBC}

As a graduate student, I experienced new opportunities while studying at UBC. Having the opportunity to access data and read journals and articles written by scholars, and comment on them, enriched my experience of knowing how others are looking at the world of teaching and pedagogy. Moreover, it gave me a chance to compare my own experience to others' as a means to learn about new theories, notions, pedagogical implications, and instructional techniques (Brock, Yu, and Wong, 1992; Nagamine, 2007). "Writing in a journal and commenting on others' entries enables teacher-learners to see that feelings, issues, accomplishments, and problems about teaching are common and removes typical feelings of isolation that come with classroom teaching" (Gebhard, 2009, p. 358). As teacher-learners progress in their learning, reading such articles and journals enhances their abilities to understand teaching and identify salient features that are related to their careers. Likewise, it helps in strengthening their identity and building on their own knowledge. In addition, discussions in the seminars have provided me with the opportunities of knowing how other teachers from different parts of the world deal with their teaching issues, as we share our experiences and accomplishments in education. Furthermore, commenting on each other's topic and summarizing the main points that are related to the core theme of discussion are all key features that are considered supportive, normative, valuable, and applicable to real life.

\section{Education, Learning a Language, and Islam}

As an international language, English is widely spoken and used nowadays. There is hardly any country that does not use English. It gives people the power to access several communities and communicate with the world. Even for Muslims it has been used for shaping their identities and their thoughts, and it has been used to value the importance of acquiring contemporary knowledge.

Recently, there has been a significant step forward in education policy in Saudi Arabia, which is demonstrated in two main reform efforts: one of them is the scholarship program, and the other one is the growing number of the universities in the Kingdom which tripled over the last decade from 7 to 24, including Prince Nora bint Abdulrahman University, which is the largest female university in the world. Another one is King Abdullah University of Science 
and Technology (KAUST), where students receive free education in English, scholarships, and monthly stipends. It is important to emphasize that women in Saudi Arabia are receiving high regard and they have almost equal opportunities as men in education.

Since Saudi people are strongly connected to Islam, which is the main religion in Saudi Arabia, they tend to follow its traditions in most aspects of life. English is the second language in Saudi Arabia, either because of career requirements or business contacts with other nations. Those who can master English have better job opportunities that require good verbal communication skills, ability to write business reports, and ability to communicate with foreign companies in English. In addition to that, society has high regard for those who can speak English fluently and use it professionally, as Al-Jarf, (2008) demonstrated in her study of the college students' views of the status of English and Arabic in Saudi Arabia in the $21^{\text {st }}$ century, “...people who study in English are more qualified and have a better social status than those who study in Arabic" (p. 202).

Learning other languages is promoted in Islam and it does not contradict with its teachings. Therefore, there is a link between our identity as teachers and the spiritual values of Islam, and it certainly appears in our actions in the classroom. Johnston asserted, "...of all the different kinds of beliefs we can hold, religious beliefs are the most personal, the most deeply held, and the most closely linked with our identity" (as cited in Johnson, 2003, p. 789). A study which was conducted by Al-Haq \& Smadi (1996) indicated that learning English in Saudi Arabia does not mean detaching oneself from the culture or being Westernized. Moreover, the Saudi university students agreed that they use English as a means for enriching their cultural personalities and developing the Kingdom of Saudi Arabia economically. The findings of the study that was conducted by Al-Jarf (2008) indicated that "...96\% of the participants consider English a superior language to Arabic because they think that the world has become a small village and English is the dominant language and the language of communication in this global village" (p. 199). In addition, English does not affect their strong connections with Islam and their national identity. English has been also used not only for educational and economic purposes, but also for religious purposes, such as preaching Islam to non-Muslims. Even religious scholars are using English in their publications to reflect the positive aspects of Islam to the world, especially after 9/11. An example of an English books that is considered to be one of the bestsellers is a book called Do Not Be Sad by AL-Qarni (2003). This book exceeded one million readers around the world as it discusses what happiness means from the Islamic perspective.

From my own experience as a teacher, most parents encourage their children to learn English and to acquire the basic knowledge of it. They did not want their children to be detached from the rest of the world. With modern technology, my students want to know how to understand others and how to acknowledge the great amount of information that they are exposed to through social media. Some schools are giving diplomas in English language proficiency in the programs where all subjects are taught in English, in addition to the degree they are studying. However, parents at the same time want their children to learn Arabic and to be well educated in religion. As a result, most people in Saudi Arabia see English as an important language and they consider learning it as an advantage in addition to learning their native language.

Washima et al., (1996: 230) indicated that according to one of the students "Western culture does not necessarily mean negative culture. We can learn English but not copy the Western way of life" (as cited in Mohd-Asraf, 2005, p. 112). Al-Attas, a prominent thinker in the contemporary Muslim world, indicated in his publications (1980-1995), the languages of all Muslim peoples have been infused by "Islamic basic vocabulary" (Mohd-Asraf, 2005, p. 114). Al-Attas (1978) also indicated, "Muslim identity is defined by Islam, which contains within itself principles and institutions stressing permanence, although allowing for necessary change, and which defines acceptable codes of behavior; sets limits on what Muslims are allowed to do, and is the lens through which many Muslims filter what is considered good, ethical, and so on" (Iqbal, 1965; Wan Daud, 1989, 1998) (as cited in Mohd-Asraf, 2005, p. 114). Thus, Muslims tend to use Islam as a framework not only as a religion, but also as a culture, a way of life, and a civilization. As Prophet Muhammad, Peace Be Upon Him (PBUH) said, "It is compulsory for every Muslim men and women to acquire knowledge" and also "I am sent as a teacher" and "God has revealed to me, Whoever walks in the pursuit of knowledge I facilitate for him the way to heaven." These quotes indicate that Islam pays great attention to education. In discussing women's education in Islam, Islam pays great respect to women, which is rooted in history. For example, Fatima, prophet Muhmmed's daughter, is cited in many historical documents as being politically active. Also, Khadija, the first of prophet Mohammed's wives, managed a successful commercial endeavor and was the first prominent businesswoman in Islam (Hamdan, 2005, p. 54). Therefore, education is highly promoted for both males and females in Islam. 


\section{English Education in Saudi Arabia}

\subsection{Does Language Teaching Mean Culture Teaching?}

Many scholars in Saudi Arabia argued that some textbooks and course materials used in teaching English are not suitable for learners in Saudi Arabia due to the cultural differences. Belonging to a culture where Islam is the dominant function in most of the educational curricula, those texts and materials should include some cultural components that reflect the learners' mother tongue culture (Benahnia, n.d.). Therefore, most of the textbooks are reviewed and edited by Saudi editors to include cultural and religious components in the topics and themes of the textbooks. For intermediate levels, there is a series of books called Say it in English that is divided into units and lessons according to the four skills of English. As a teacher, I found the textbook offering a variety of interesting topics with opportunities to foster learners' cultural identity. Benahnia (n.d.) argued that, “... textbooks are one of the keys that can help the learners improve their cultural competence and realize their own identity" (p. 7).

Say it in English not only focuses on the Saudi culture but also exposes the learners to a wide variety of cultures by comparing and contrasting them in terms of the traditional marriages, entertainments, types of food, and other characteristics so that they trigger intercultural competence and identity. To answer the above question, Benahnia (n.d.) suggested a moderate answer as he said, "learners at the beginning level should not be fully exposed to the target language culture. On the contrary, they should be exposed mostly to their L1 [first language] culture or Mother Tongue language culture, the reason behind that is to give them self-confidence and ability to talk to other people about their own cultural elements and issues related to their surrounding" (p. 8).

Another important resource that I was using in teaching is the online discussions in the forum, which belongs to the Ministry of Higher Education in Saudi Arabia. This forum is in fact designed for engaging teachers, both males and females, throughout the Kingdom, in discussions about the curriculum, and encourages them to post their teaching strategies. The forum tends to serve other college and university students. A study that was conducted by Al-Jarf (2006) indicated that the forum with its various participants promoted asynchronous self-directed learning and peer support and she mentioned, "They provide an opportunity for cognitive, social, and teaching presences, essential for the successful development of online learning communities" (p. 9). The forum significantly helped me during my practicum and also helped me to prepare work sheets, quizzes, and final exams according to the requirements of the Ministry.

\section{Higher Education and Beyond in Saudi Arabia}

\subsection{King Abdullah Scholarship Program}

As a student sponsored by the Ministry of Higher Education in Saudi Arabia, I would like to point out the objectives of the scholarship program that started in 2005 as a part of developing the Kingdom. The program supports studying different fields in Medicine, Pharmacy, Nursing, Engineering, and many other disciplines for pursuing bachelor, master, doctorate degrees, as well as medical residency requirements, and fellowship programs. Furthermore, the program not only sponsors males but also females, and the number of females studying abroad has been increasing recently. The estimate from the Saudi Ministry of Higher Education in 2011 suggested that, “...almost 25,000 Saudi females are currently financially supported by the government to study abroad, which represents around $20 \%$ of all Saudi higher education scholarship recipients"( Bukhari \& Denman, in Smith \& Abouammoh , 2013, p.157 ). The government is aiming to create a community that is able to engage internationally and gain knowledge from other parts of the world. Since coming to Canada, I tried to learn from all the relevant courses that were offered to me. Another objective was to communicate with other people and to change their misconceptions about Islam. The engagement in conversations with other people and the extensive data I have obtained during my studies have widened my perspectives on teaching as a career.

\section{Conclusion}

In conclusion, I would like to describe my identity in learning and teaching a second language as a plant growing and prospering. Life keeps teaching us lessons that add to our experience and contribute to changing and transforming our identities. Our identity will keep changing over time and space whenever we are exposed to new experiences of both teaching and learning. Capturing the images of diverse identities in my life has been a valuable experience because it has given me the opportunity to explore what impacts identity and how identity affects my practice as an English language teacher in Saudi Arabia.

Since my topic focused mainly on identity and other theories related to identity, it was inspiring to explore this topic 
in greater depth. It has given me insight into understanding myself better as a teacher and a second language learner. The benefits that I have gained after writing and reading about identity motivate me to understand my students' identities and the circumstances around the development of their identity. This will help me to help my students attain their imagined identities in the future.

\section{Acknowledgement}

I would like to express my gratitude to my supervisor, Dr. Bonny Norton, who helped me to formulate the topic of my paper and for her support and feedback throughout the different stages of the paper. I would like also to thank all my professors at The University of British Columbia for allowing me to access the world of knowledge and who helped me enormously by providing feedback and comments throughout my studying. Special thanks for my family and my friends who were by my side and supportive during studying abroad and who encouraged me to pursue my educational goals.

"Our Lord, for You is all praise, an abundant beautiful blessed praise"

\section{References}

Al-Jarf, R. (2006, May 4-5). Teachers' online discussion forums in Saudi Arabia. Paper presented at the International Conference. Canakkale, Turkey.

Al-Jarf, R. (2008). The impact of English as an international language (EIL) upon Arabic in Saudi Arabia. Asian EFL Journal, 10(4), 193-210.

Al-Seghayer, K. (2012, December 11). Status and functions of English in Saudi Arabia. Saudi Gazette. Retrieved from http://www.saudigazette.com.sa/index.cfm?method=home.regcon\&contentid=20121211145659

Benahnia, A., (n.d.). The Role of Cultural Components in Shaping the L2 Learner's Identity and Intercultural Competence. $\quad$ Retrieved http://www.ksaalt.org/conference\%20proceedings/Finalized_Dr_Abdellah_Oct_30.pdf

Block, D. (2011). Identity in Applied Linguistics. In Wei, L (Ed.), The Routldge Applied Linguistics Reader (250). London: Routledge.

Bukhari, F., \& Denman, B. (2013). Student Scholarships in Saudi Arabia: Implications and Opportunities for Overseas Engagement. In Smith, L., \& Abouammoh, A. (Eds.), Higher education in Saudi Arabia (pp. 151-158). DE: Springer Verlag.

Bullough Jr, R., \& Baughman, K. (1993). Continuity and change in teacher development: First year teacher after five years. Journal of Teacher Education, 44(2), 86. http://dx.doi.org/10.1177/0022487193044002003

Burns, A., \& Richards, J. C. (Eds.). (2009). The Cambridge guide to second language teacher education. New York: Cambridge University Press.

Clary, C., \& Karlin, M. (2011). Saudi Arabia's reform gamble. Survival, 53(5), 15-20.

Farrell, T. (2009). The novice teacher experience. In Burns, A., \& Richards, J. C. (Eds.), The Cambridge guide to second language teacher education. (pp. 261-268). New York: Cambridge University Press.

Flores, M. A. (2001). Person and context in becoming a new teacher. Journal of Education for Teaching, 27(2), 135-48. http://dx.doi.org/10.1080/02607470120067882

Fuller, F., \& Brown, O. (1975). Becoming a teacher. In K. Ryan (Ed.), Teacher education: Seventy-fourth yearbook of the National Society for the Study of Education. Chicago: University of Chicago Press.

Furness, A. (2008). Formation of ESL teacher identity during the first year: an introspective study. In Farrell, T. Editor, Novice language teachers: Insights and perspectives for the first year (pp. 150-157). Oakville, CT: Equinox Publishing Ltd.

Gebhard, J. (2009). The practicum. In Burns, A., \& Richards, J. C. (Eds.), The Cambridge guide to second language teacher education. (pp. $354-361$ ). New York: Cambridge University Press.

Hamdan, A. (2005). Women and education in Saudi Arabia: Challenges and achievements. International Education Journal, 6(1), 42-64.

HAQ, F. A. A., \& SMADI, O. (1996). Spread of English and westernization in Saudi Arabia. World Englishes, 15(3), 307-317. http://dx.doi.org/10.1111/j.1467-971X.1996.tb00117.x 
Johnson, K. A. (2003). Every experience is a moving force: Identity and growth through mentoring. Teaching and Teacher Education, 19(8), 787-800. http://dx.doi.org/10.1016/j.tate.2003.06.003

Johnson, K. E. (1992). Learning to teach: Instructional actions and decisions of preservice ESL teachers. TESOL Quarterly, 26(3), 507-535.

Johnson, K. E. (2009). Teachers as learners of teaching. In Second Language Teacher Education: A Sociocultural Perspective (pp. 17-40). New York: Routledge, Print.

Johnston, B. (2009). Collaborative teacher development. In Burns, A., \& Richards, J. C. (Eds.), The Cambridge guide to second language teacher education. (pp. 341 -349). New York: Cambridge University Press.

Kanno, Y., \& Norton, B. (2003). Imagined communities and educational possibilities: Introduction. Journal of Language, Identity \& Education, 2(4), 241-249. http://dx.doi.org/10.1207/S15327701JLIE0204_1

Kanno, Y., \& Stuart, C. (2011). Learning to become a second language teacher: Identities-in-practice. The Modern Language Journal, 95(2), 236-252. http://dx.doi.org/10.1111/j.1540-4781.2011.01178.x

Krieger, Z. (2007, September 14). Saudi Arabia puts its billions behind Western-style higher education. The Chronicle of Higher Education, 54(3), A1.

Lave, J., \& Wenger, E. (1991). Situated learning: Legitimate peripheral participation. New York: Cambridge University Press.

Llurda, E. (2004). Non-native-speaker teachers and English as an international language. International Journal of Applied Linguistics, 14(3), 314-323. http://dx.doi.org/10.1111/j.1473-4192.2004.00068.x

Malderez, A. (2009). Mentoring. In Burns, A., \& Richards, J. C. (Eds.), The Cambridge guide to second language teacher education. (pp. 366 - 375). New York: Cambridge University Press.

Mohd-Asraf, R. (2005). English and Islam: A clash of civilizations? Journal of Language, Identity, and Education, 4(2), 103-118. http://dx.doi.org/10.1207/s15327701jlie0402_3

Morgan, B. (2004). Teacher identity as pedagogy: Towards a field-internal conceptualisation in bilingual and second language education. International Journal of Bilingual Education and Bilingualism, 7(2-3), 172-188. http://dx.doi.org/10.1080/13670050408667807

Norton, B. (1997). Language, identity, and the ownership of English. TESOL Quarterly, 31(3), 409-409.

Norton, B. (2000). Identity and language learning: Gender, ethnicity, and educational change. New York: Longman.

Norton, B., \& McKinney, C. (2011). Identity and Second Language Acquisition. In D. Atkinson (Ed.), Alternative approaches to Second Language Acquisition. (pp. 75-78-80). New York: Routledge.

Norton, B., \& Toohey, K. (2001). Changing perspectives on good language learners. TESOL Quarterly, 35(2), 307-322.

Norton, B., \& Toohey, K. (2011). Identity, language learning, and social change. Language Teaching, 44(4), 417. http://dx.doi.org/10.1017/S0261444811000309

Peirce, B. N. (1995). Social identity, investment, and language learning. TESOL Quarterly, 29(1), 9-31.

Pittaway, D. S. (2004). Investment and second language acquisition. Critical Inquiry in Language Studies, 1(4), 203-218. http://dx.doi.org/10.1207/s15427595cils0104_2

Reeves, J. (2009). Teacher investment in learner identity. Teaching and Teacher Education, 25(1), 34-41. http://dx.doi.org/10.1016/j.tate.2008.06.003

Richards, J. C. (1996). Teachers' maxims in language teaching. TESOL Quarterly, 30(2), 281-296.

Richards, J. C. (2008). Second language teacher education today. RELC Journal, 39(2), 158-177. http://dx.doi.org/10.1177/0033688208092182

Saudi Arabia achieves $96 \%$ literacy rate. (2012, September 08). Saudi Gazette. Retrieved from http://www.saudigazette.com.sa/index.cfm?method=home.regcon\&contentid=20120908135487

Saudi Arabia looks eastwards for higher education. (2006b, March 30). The Ultimate Middle East Business Resource. Retrieved from http://www.ameinfo.com/news/Detailed/81824.html

Singh, G., \& Richards, J. (2006). Teaching and learning in the language teacher education course room: A critical sociocultural perspective. RELC Journal, 37(2), 149-175. http://dx.doi.org/10.1177/0033688206067426 
Uddin, M. J., \& Salam, A. (2010). Effective teaching and learning. Medicine Today, 22(1), 32-33. http://dx.doi.org/10.3329/medtoday.v22i1.5603

Varah, L., Theune, W., \& Parker, L. (1986). Beginning teachers: Sink or swim? Journal of Teacher Education, 37(1), 30-34. http://dx.doi.org/10.1177/002248718603700107

Varghese, M., Morgan, B., Johnston, B., \& Johnson, K. (2005). Theorizing language teacher Identity: Three perspectives and beyond. Journal of Language, Identity, \& Education, 4(1), 21-44. http://dx.doi.org/10.1207/s15327701jlie0401_2 